\title{
Fly Ash Porous Material using Geopolymerization Process for High Temperature Exposure
}

\section{Mohd Mustafa Al Bakri Abdullah ${ }^{1}$ *, Liyana Jamaludin ${ }^{1}$, Kamarudin Hussin ${ }^{1}$, Mohamed Bnhussain ${ }^{2}$, Che Mohd Ruzaidi Ghazali ${ }^{1}$ and Mohd Izzat Ahmad ${ }^{1}$}

1 School of Material Engineering, University Malaysia Perlis (UniMAP), P.O. Box 77, D/A Pejabat Pos Besar, Kangar, Perlis 01000, Malaysia; E-Mails: liyanajamaludin@unimap.edu.my (L.J.); vc@unimap.edu.my (K.H.); ruzaidi@unimap.edu.my (C.M.R.G.); ifan_7818@yahoo.com (M.I.A.)

King Abdul Aziz City Science \& Technology (KACST), P.O. Box 6086, Riyadh 11442,

Kingdom of Saudi Arabia; E-Mail: bnhusain@kacst.edu.sa

* Author to whom correspondence should be addressed; E-Mail: mustafa_albakri@ unimap.edu.my; Tel.: +6-012-5055020; Fax: +6-04-9798178.

Received: 13 January 2012; in revised form: 24 February 2012 / Accepted: 19 March 2012 /

Published: 10 April 2012

\begin{abstract}
This paper presents the results of a study on the effect of temperature on geopolymers manufactured using pozzolanic materials (fly ash). In this paper, we report on our investigation of the performance of porous geopolymers made with fly ash after exposure to temperatures from $600{ }^{\circ} \mathrm{C}$ up to $1000{ }^{\circ} \mathrm{C}$. The research methodology consisted of pozzolanic materials (fly ash) synthesized with a mixture of sodium hydroxide and sodium silicate solution as an alkaline activator. Foaming agent solution was added to geopolymer paste. The geopolymer paste samples were cured at $60{ }^{\circ} \mathrm{C}$ for one day and the geopolymers samples were sintered from $600{ }^{\circ} \mathrm{C}$ to $1000{ }^{\circ} \mathrm{C}$ to evaluate strength loss due to thermal damage. We also studied their phase formation and microstructure. The heated geopolymers samples were tested by compressive strength after three days. The results showed that the porous geopolymers exhibited strength increases after temperature exposure.
\end{abstract}

Keywords: geopolymer; pozzolanic material; thermal analysis 


\section{Introduction}

In 1978, Davidovits introduced the word "geopolymer" to describe an alternative cementitious material which has ceramic-like properties [1]. Geopolymer technology has the potential to reduce emissions by $80 \%$ because high temperature calcining is not required [2]. It also exhibits ceramic-like properties with good resistance to fire at elevated temperature. Geopolymer are amorphous to semi crystalline equivalent of certain zeolitic materials with excellent properties such as high fire and erosion resistances and high strength materials [3]. Materials that use fewer natural resources, require less energy, and generate less $\mathrm{CO}_{2}$ are referred to as green materials. Fly ash refers to the inorganic, incombustible matter present in coal that is fused into a glassy, amorphous structure during the combustion process [4]. Geopolymer is a man-made material with many exceptional properties including impressive fire resistance and the capacity to encapsulate hazardous waste [5].

The alkaline liquid could be used to react with the silicon ( $\mathrm{Si}$ ) and the aluminum (Al) in a source material of natural minerals or in by-product materials such as fly ash and rice husk to produce binders [6]. Fly ash geopolymer does not require high temperature processing. Fly ash-based geopolymer with $12 \mathrm{M} \mathrm{NaOH}$ concentration shows excellent result with high compressive strength (94.59 MPa) for the 7th day of testing [3]. Palomo et al. (1999) reported that an activator with a $12 \mathrm{M}$ of $\mathrm{NaOH}$ concentration leads to better results than an $18 \mathrm{M}$ of $\mathrm{NaOH}$ concentration. In addition, the researchers used a ratio of fly ash to alkaline activator in the range of 2.5 to 3.3 to achieve optimum parameters with better strength [3]. Samples cured at $70{ }^{\circ} \mathrm{C}$ provided the concrete with good strength and workability properties [7]. Some researchers have described the alkali activation of fly ash (AAFA) as a physical-chemical process in which the powdery solid is mixed with a concentrated alkali solution in a suitable proportion to produce a workable and mouldable paste, which is stored at mild temperatures $\left(<100^{\circ} \mathrm{C}\right)$ for a short period of time to produce a material with good binding properties [8].

High temperature performance of geopolymers are investigated and presented in this paper with a view to produce an alternative refractory material. Cement is produced by heating a powdered mixture of limestone, clay, ferrous materials, and siliceous materials to temperature of $1500{ }^{\circ} \mathrm{C}$ [1]. Geopolymer can be produced by combining pozzolanic compound or aluminosilicate source material with highly alkaline solution [5]. Their physical behavior is similar to that of OPC and has been considered as a possible improvement on cement in respect of compressive strength, resistance to fire, heat and acidity, and as a medium for the encapsulation of hazardous or low/intermediate level radioactive waste [9-12]. In the present work we briefly investigated a geopolymer which is suitable for high temperature application.

\section{Results and Discussion}

\subsection{Physical Behavior of Porous Geopolymer after Sintering}

Physical observations showed the decolorization of all specimens after sintering. The dimensional change did not exhibit after sintering at high temperature. Observations showed few cracks after exposure to elevated temperatures. The average mass reduction compared with geopolymer before sintering for different mass ratios and temperature are summarized in Table 1. 
Table 1. Percentage of mass reduction of sintered porous geopolymer samples.

\begin{tabular}{cccc}
\hline Ratio & \multicolumn{3}{c}{ Mass reduction (\%) } \\
\cline { 2 - 4 } $\mathbf{N a}_{2} \mathbf{S i O}_{\mathbf{3}} / \mathbf{N a O H}$ & $\mathbf{6 0 0}^{\circ} \mathbf{C}$ & $\mathbf{8 0 0}^{\circ} \mathbf{C}$ & $\mathbf{1 0 0 0}^{\circ} \mathbf{C}$ \\
\hline 2.5 & 17.32 & 19.45 & 22.36 \\
3.0 & 17.80 & 19.50 & 22.65 \\
3.5 & 17.95 & 19.70 & 27.35 \\
\hline
\end{tabular}

\subsection{Compressive Strength}

The compressive strength of porous geopolymer samples were measured using mechanical testing with Automatic Max (Instron, 5569 USA). The strength of samples was tested three days after casting. Physical observations showed the decolorization of all specimens. Figure 1 represents the compressive strength development of porous geopolymer samples before and after temperature exposure with various $\mathrm{Na}_{2} \mathrm{SiO}_{3} / \mathrm{NaOH}$ ratio results ranging from 2.5 to 3.5. The compressive strength of geopolymer significantly improved with increasing sintering temperature and as the ratio increased. An increase in $\mathrm{Na}_{2} \mathrm{SiO}_{3} / \mathrm{NaOH}$ ratio results in an increase of $\mathrm{Na}$ content in the mixtures which in turn produce more stable strength properties [13]. Rapid strength development occurs within geopolymers with higher concentrations of $\mathrm{NaOH}$ [14]. As presented in Table 2, the highest compressive strength, $42.40 \mathrm{MPa}$, was achieved after three days with the 3.5 ratio of $\mathrm{Na}_{2} \mathrm{SiO}_{3} / \mathrm{NaOH}$ and highest sintering temperature of $1000{ }^{\circ} \mathrm{C}$. Geopolymer samples withstand a maximum application temperature of approximately $1000{ }^{\circ} \mathrm{C}[15]$.

Table 2. Geopolymer samples strength results.

\begin{tabular}{ccccc}
\hline \multirow{2}{*}{$\begin{array}{c}\text { Ratio } \\
\text { Na2SiO3/NaOH }\end{array}$} & \multicolumn{4}{c}{ Compressive strength after 3 days (Mpa) } \\
\cline { 2 - 5 } & unsintered & $\mathbf{6 0 0}{ }^{\circ} \mathbf{C}$ & $\mathbf{8 0 0}{ }^{\circ} \mathbf{C}$ & $\mathbf{1 0 0 0}{ }^{\circ} \mathbf{C}$ \\
\hline 2.5 & 12.12 & 10.41 & 8.90 & 8.63 \\
3.0 & 15.56 & 10.04 & 24.00 & 22.83 \\
3.5 & 21.99 & 14.63 & 24.33 & 42.40 \\
\hline
\end{tabular}

Figure 1. Effect of unsintered and sintered temperature of porous geopolymer on compressive strength.

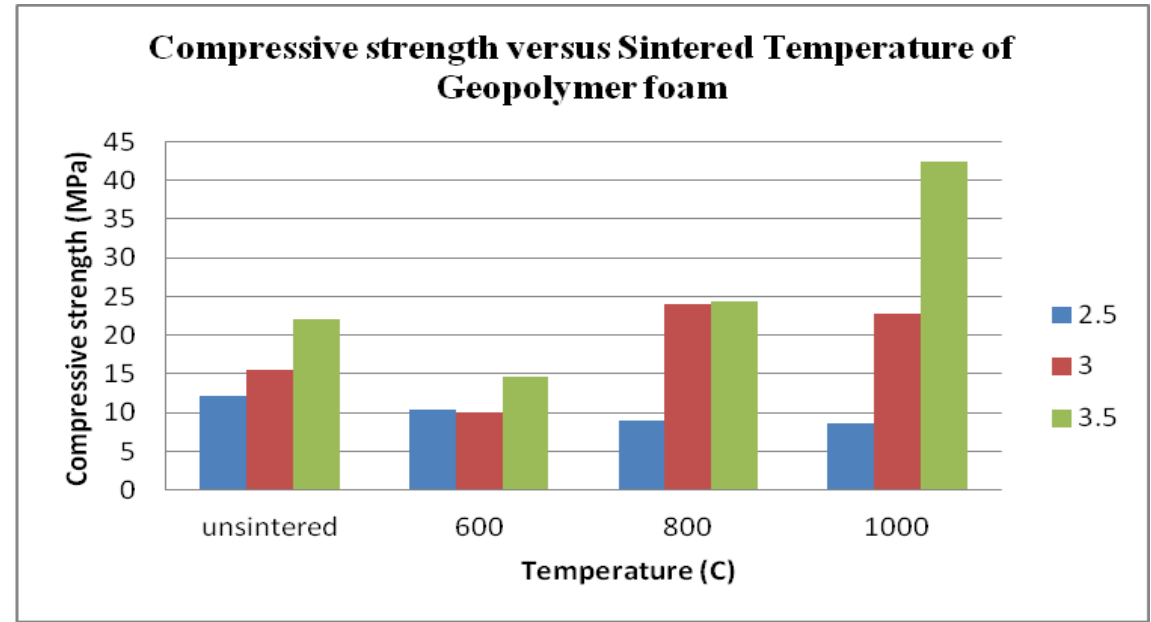




\subsection{Scanning Electron Microscopy Analysis}

The microstructure of porous geopolymer in Figure 2 shows the formation of porous heterogeneous matrix which does not exist in the original fly ash. It can be seen that porous geopolymers with lower ratio have more open porosity and the open porosities of porous geopolymers decrease with increasing heat treatment temperatures. The increase in porosity is attributed to sintering possibility by assistance from a liquid phase.

Figure 2. Porous geopolymer microstructure before temperature exposure.

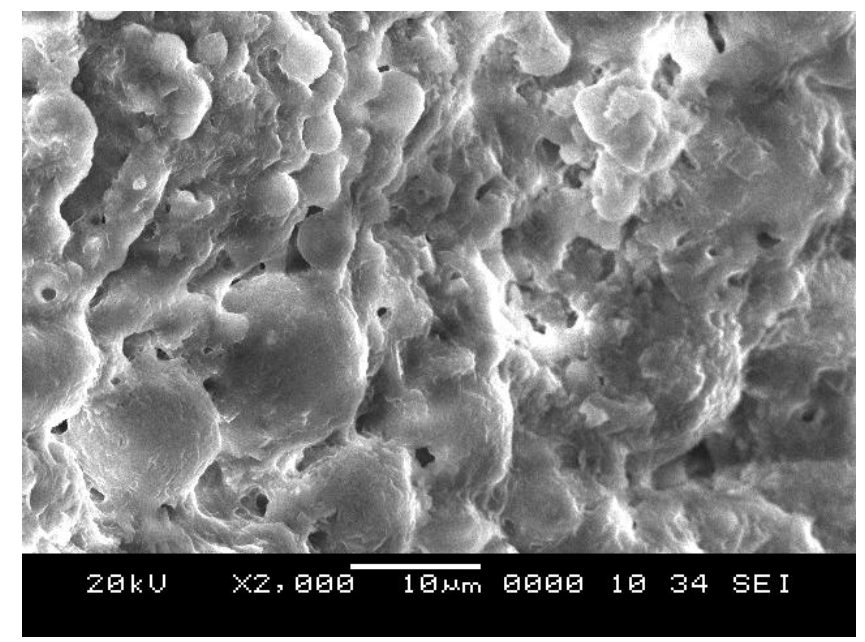

The SEM image for the porous geopolymer heated to $1000{ }^{\circ} \mathrm{C}$ shows a microstructure that appears to contain relatively less unreacted fly ash microspheres proportions. Porous geopolymer after temperature exposure is shown in Figure 3. Figure 4 shows hollow cavities due to spaces left behind by dissolved fly ash particles. The pore sizes in the geopolymer after temperature exposure were $10 \mu \mathrm{m}-20 \mu \mathrm{m}$. Porosity is caused by different developments of microstructure skeletons in the porous geopolymer. The solid-to-liquid ratio affects the volume of voids and porosity in the geopolymer which directly influences the strength of geopolymer.

Figure 3. Porous geopolymer after $1000^{\circ} \mathrm{C}$ temperature exposure.

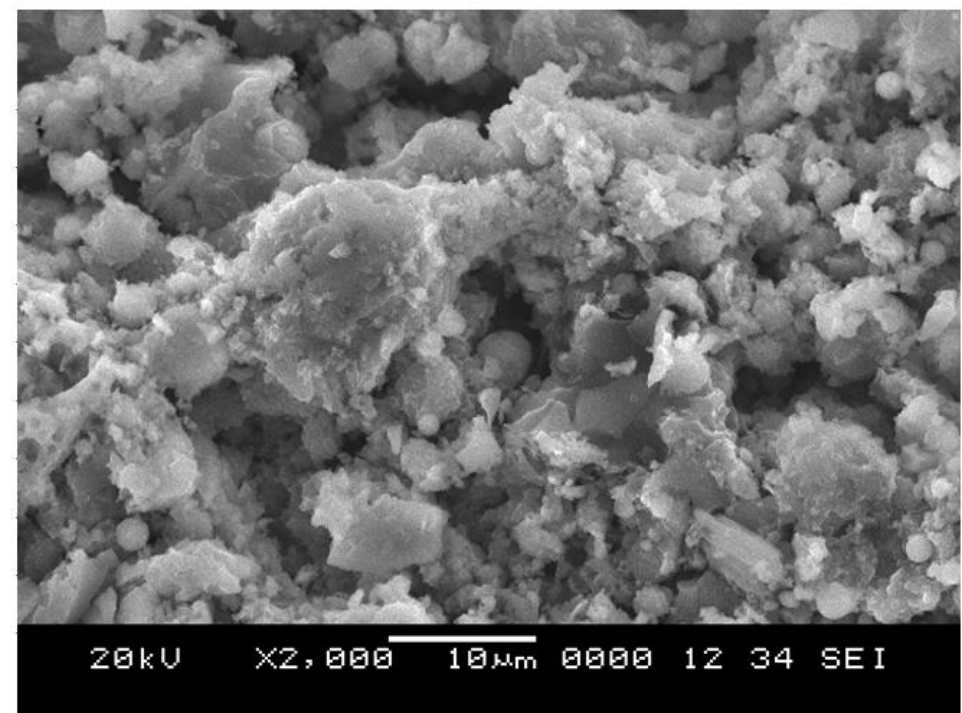


Figure 4. Hollow cavities of geopolymer porous sample.

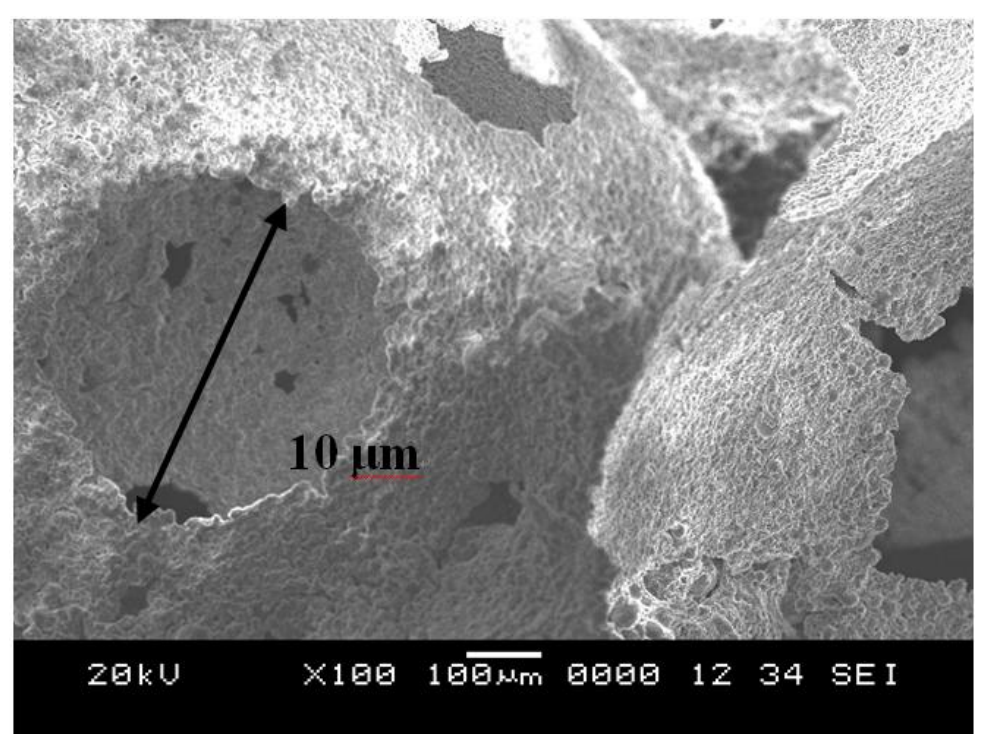

\subsection{Water Absorption and Porosity}

The water absorption of geopolymer samples was determined with different water/solids ratios. Water absorption can be used to represent an open porosity of geopolymer. The measurement is taken by calculating the difference in specimen weight under over-dried and fully saturated conditions. The percentage of water absorption for all geopolymer samples varied in the range 2.56 to $4.49 \%$ at three days of the geopolymer age. The water absorption of fly ash geopolymer normally varies between 3 and 5\% [16]. When high alkaline solution is added to the mixture, the water absorption tends to increase. A mix with a high amount of alkaline activator solution will produce a more porous geopolymer gel. A high amount of sodium silicate ratio in a mixture was found to produce geopolymer concrete with large pore sizes [17]. This explains the tendency of a mixture with high alkaline content to have higher porosity than mixes with low alkaline ratios.

\section{Experimental Setup}

\subsection{Materials}

Fly ash obtained from Manjung power station in Lumut, Perak, Malaysia was used as base materials to produce the geopolymers sample.

Sodium silicate $\left(\mathrm{Na}_{2} \mathrm{SiO}_{3}\right)$ mixed with sodium hydroxide $(\mathrm{NaOH})$ used as an alkaline activator for this research. $\mathrm{NaOH}$ in pellet form with $97 \%$ purity (Vijaya Rangan, 2008) and $\mathrm{Na}_{2} \mathrm{SiO}_{3}$ consists of $\mathrm{Na}_{2} \mathrm{O}=9.4 \%, \mathrm{SiO}_{2}=30.1 \%$ and $\mathrm{H}_{2} \mathrm{O}=60.5 \%$, with mass ratio $\mathrm{SiO}_{2} / \mathrm{Na}_{2} \mathrm{O}=3.20-3.30$ ). Foaming agents, including spherical $\mathrm{Al}$ powder and hydrogen peroxide, were added to the geopolymer paste to control porosity into the material and to shorten the diffusion distance for entrapped water to leave the samples. 


\subsection{Mixture Compositions}

Geopolymer materials were prepared by mixing alumino-silicate with the alkaline activator solution. The alkaline activator solutions were prepared by the dissolution of sodium hydroxide in one liter of distilled water in a volumetric flask to obtain a $12 \mathrm{M}$ concentration. Alkaline activator, which consisted of the combination of $\mathrm{NaOH}$ and $\mathrm{Na}_{2} \mathrm{SiO}_{3}$, was prepared just before it was to be mixed with the fly ash. The sodium silicate was added to enhance the process of geopolymerization [18]. The ratio of pozzolanic materials/alkaline activator and $\mathrm{Na}_{2} \mathrm{SiO}_{3} / \mathrm{NaOH}$ used was 2.5, 3.0 and 3.5 for all mixtures. This particular ratio was used based on the work of Hardjito et al. (2008) in which it was stated that this ratio produced the highest compressive strength [19]. Table 3 shows a mixture with proportions of geopolymer paste with different ratios of $\mathrm{Na}_{2} \mathrm{SiO}_{3} / \mathrm{NaOH}$.

Table 3. Mixture proportions of geopolymer paste.

\begin{tabular}{lccc}
\hline Mixture of geopolymer & Mass ratios (2.5) & Mass ratios (3.0) & Mass ratios (3.5) \\
\hline Ratio of fly ash/alkaline & 2.5 & 3.0 & 3.5 \\
activator & 2.5 & 3.0 & 3.5 \\
Ratio $\mathrm{Na}_{2} \mathrm{SiO}_{3} / \mathrm{NaOH}$ & 1210 & 1270 & 1310 \\
Mass of fly ash $(\mathrm{g})$ & 137.8 & 105.5 & 83.3 \\
Mass of $\mathrm{NaOH}(\mathrm{g})$ & 344.4 & 316.4 & 291.7 \\
Mass of $\mathrm{Na}_{2} \mathrm{SiO}_{3}(\mathrm{~g})$ & &
\end{tabular}

\subsection{Samples Preparation}

The alkaline solution was added to the geopolymeric precursor (fly ash) and mixed for 5 min to obtain a homogeneous mixture. Foaming agent solution was added to geopolymer paste to get porous geopolymer. The geopolymer mixture formed a slurry paste and was poured into a steel sample mould $(50 \mathrm{~mm} \times 50 \mathrm{~mm} \times 50 \mathrm{~mm})$ which was then allowed to stand at room temperature for a few hours.

\subsection{Curing Regime and High Temperature Exposure}

Geopolymer paste was cured in the oven for one day at constant temperature of $60{ }^{\circ} \mathrm{C}$ [7]. At the end of curing regime, the samples were removed from their molds and allowed to cool before initial qualitative observations were recorded.

To study the effect of heating on the microstructure and loss of water, the cured porous geopolymer were heated at $600{ }^{\circ} \mathrm{C}, 800{ }^{\circ} \mathrm{C}$, and $1000{ }^{\circ} \mathrm{C}$ for three hours in box furnace with heating and cooling rates $5^{\circ} \mathrm{C} / \mathrm{min}[20]$. The unexposed samples were left undisturbed at ambient temperature.

\subsection{Compressive Test}

The compressive strength of geopolymer samples were measured according to BS 1881-116:1983 using mechanical testing with Automatic Max (Instron, 5569 USA) in order to obtain the ultimate strength of geopolymer. The samples were compressed with $50 \mathrm{kN}$ load and with loading rate of $5 \mathrm{~mm} / \mathrm{min}$. 


\subsection{Microstructure Analysis Test}

Scanning electron microscopy (SEM) was performed using SEM JSM-6460 LA Jeol Japan in School of Materials Engineering, University Malaysia Perlis (UniMAP) to analyze the microstructure of the fly ash and porous geopolymer samples. The test was conducted using secondary and backscattered electron detectors. SEM analysis was done at the accelerating voltage of $20 \mathrm{kV}$. Samples of fly ash were prepared in powder form and the other porous geopolymer samples were placed on the sample holders supported by carbon tape.

\section{Conclusions}

In conclusion, the fly ash porous geopolymer displayed increase in strength after temperature exposure of $1000{ }^{\circ} \mathrm{C}$. This is attributed to the increase in a combination of polymerization reaction and sintering at high temperature. The fly ash-to-activator ratio can be an important parameter regarding strength and sintering temperature of the porous geopolymer. Fly ash porous geopolymer with a ratio 3.5 of $\mathrm{Na}_{2} \mathrm{SiO}_{3} / \mathrm{NaOH}$ shows excellent results with high compressive strength (42.4 MPa) after 3 days of testing, even after high temperature exposure.

\section{Acknowledgments}

This study was funded by King Abdul Aziz City Science and Technology (KACST). The authors extend their thanks and appreciation to Centre of Excellence Geopolymer \& Green Technology (CEGeoGTech) and the School of Material Engineering, Universiti Malaysia, Perlis (UniMAP) for their support.

\section{References}

1. Davidovits, J. Geopolymer cement to minimize carbon-dioxide greenhouse-warming. Ceram. Trans. 1993, 37, 165-182.

2. Davidovits, J. Global warming impact on the cement and aggregates industries. World Resour. Rev. 1993, 6, 263-278.

3. Mustafa Albakri, A.M.; Kamarudin, H.; Bnhussain, M.; Khairul Nizar, I.; Rafiza, A.R.; Zarina, Y. Microstructure of different $\mathrm{NaOH}$ molarity of fly ash-based green polymeric cement. J. Eng. Technol. Res. 2011, 3, 44-49.

4. Davidovits, J. Geopolymers: Inorganic polymeric new materials. J. Therm. Anal. 1991, 37, 1633-1656.

5. Thomas Paul, K.; Satpthy, S.K.; Manna, I.; Chakraborty, K.K.; Nando, G.B. Preparation and characterization of nano structured materials from fly ash: A waste from thermal power stations, by high energy ball milling. Nanoscale Res. Lett. 2007, 2, 397-404.

6. Davidoits, J. High-alkali Cements for 21st Century Concretes. In Concrete Technology Past, Present and Future; Mehta, P.K., Ed.; American Concrete Institute: Detroit, MI, USA, 1994; SP-144, pp. 383-397. 
7. Mustafa Al Bakri, A.M.; Kamarudin, H.; Karem, O.A.K.A.; Ruzaidi, C.M.; Rafiza, A.R.; Norazian, M.N. Optimization of alkaline activator/fly ash ratio on the compressive strength of manufacturing fly ash based geopolymer. J. Appl. Mechan. Mat. 2011, 110-116, 734-739.

8. Fernandez-Jimenez, A.; Palomo, A. Characterisation of fly ashes. Potential reactivity as alkaline cements. Fuel 2003, 82, 2259-2265.

9. Davidoits, J. Geopolymer: Man-Made Rock Geosynthesis and the resulting development of very early high strength cement. J. Mat. Educ. 1994, 16, 91-139.

10. Davidovits, J. Chemistry of geopolymeric systems terminology, geopolymer 99. Geopolymer Int. Conf. Proc. 1999, 11, 9-39.

11. Allahverdi, A.; Skvara, F. Nitric acid attack on hardened paste of geopolymeric cement. Ceramic-Silikatay 2001, 45, 81-88.

12. Perera, D.S.; Vance, E.R.; Aly, Z.; Finnie, K.S.; Hanna, J.V.; Nicholson, C.L.; Trautman, R.L.; Stewart, M.W.A. Characterisation of Geopolymer for the Immobilisation of Intermediate Level Waste. In Proceedings of ASME 2003 9th International Conference on Radioactive Waste Management and Environmental Remediation, Oxford, England, 21-25 Sepember 2003.

13. Daniel, L.Y.K.; Sanjayan, J.G. Damage behavior of geopolymer composites exposed to elevated temperatures. Cement Concr. Compos. 2008, 30, 986-991.

14. Chew, M.Y.L. Assessment of fire damaged concrete. Build Environ. 1993, 28, 97-102.

15. Davidovits, J. Geopolymer Chemistry \& Application, 3rd ed.; Institut Geopolymere: Paris, France, 2008.

16. Sathia, R.; Babu, K.G.; Santhanam, M. Durability study of low calcium fly ash geopolymer concrete. In Proceedings of the 3rd ACF International Conference- ACF/VCA, Ho Chi Minh City, Vietnam, 11-13 November 2008.

17. Van Jaarsveld, J.G.S.; van Deventer, J.S.J.; Lukey, G.C. The effect of composition and temperature on the properties of fly ash and kaolinite based geopolymers. Chem. Eng. J. 2002, 89, $63-73$.

18. Xu, H.; Deventer, J. The geopolymerisation of alumino-silicate minerals. Int. J. Min. Proc. 2000, 59, 247-266.

19. Hardjito, D.; Rangan, B.V. Development and Properties of Low-Calcium Fly-Ash-Based Geopolymer Concrete; Research Report GC 1, Faculty of Engineering, Curtin University of Technology, Perth, Australia, 2005.

20. Perera, D.S.; Trautman, R.L. Geopolymers with the potential for use as refractory castables. Adv. Technol. Mat. Mat. Proc. J. 2006, 2, 187-189.

21. Hardjito, D.; Cheak, C.C.; Lee, C.H. Strength and setting times of low calcium fly ash- based geopolymer mortar. Mod. Appl. Sci. 2008, 2, 3-11.

22. Rangan, B.V. Low-Calcium, Fly-Ash-Based Geopolymer Concrete. In Concrete Construction Engineering Handbook; Taylor and Francis Group: Boca Raton, FL, USA, 2008; pp. 1-19.

(C) 2012 by the authors; licensee MDPI, Basel, Switzerland. This article is an open access article distributed under the terms and conditions of the Creative Commons Attribution license (http://creativecommons.org/licenses/by/3.0/). 